\title{
Performance of Nile Tilapia and vegetables Grown in Different Aquaponic Volumes
}

\author{
Phillipe Thiago Leite Barbosa (Corresponding author) \\ Faculdade de Medicina Veterinária e Zootecnia da Universidade Federal de Mato Grosso \\ do Sul (UFMS). Avenida Senador Filinto Müller, 2443-Vila Ipiranga, 79074-460. \\ E-mail: ptlb2006@hotmail.com
}

Jayme Aparecido Povh

Faculdade de Medicina Veterinária e Zootecnia da Universidade Federal de Mato Grosso do Sul (UFMS). Avenida Senador Filinto Müller, 2443-Vila Ipiranga, 79074-460. E-mail: jayme.povh@ufms.com

André Luiz do Nascimento Silva

Faculdade de Medicina Veterinária e Zootecnia da Universidade Federal de Mato Grosso do Sul (UFMS). Avenida Senador Filinto Müller, 2443-Vila Ipiranga, 79074-460. E-mail: andre.nascimento31@gmail.com

Arlene Sobrinho Ventura

Faculdade de Medicina Veterinária e Zootecnia da Universidade Federal de Mato Grosso do Sul (UFMS). Avenida Senador Filinto Müller, 2443-Vila Ipiranga, 79074-460. E-mail: arlenesventura@gmail.com

\section{Giovanna Rodrigues Stringhetta}

Faculdade de Medicina Veterinária e Zootecnia da Universidade Federal de Mato Grosso do Sul (UFMS). Avenida Senador Filinto Müller, 2443-Vila Ipiranga, 79074-460. E-mail: gstringhetta@gmail.com

\section{Laice Menes Laice}

Agriculture Division (DivAG), Institute Higher Polytechnic of Manica, Campus of Matsinho, 417, Chimoio, Mozambique. E-mail: laicemeneslaice@gmail.com 
Antonio Francisco de Oliveira

Faculdade de Medicina Veterinária e Zootecnia da Universidade Federal de Mato Grosso do Sul (UFMS). Avenida Senador Filinto Müller, 2443-Vila Ipiranga, 79074-460. E-mail: anton.francisco37@gmail.com

Thainá Arruda de Carvalho

Faculdade de Medicina Veterinária e Zootecnia da Universidade Federal de Mato Grosso do Sul (UFMS). Avenida Senador Filinto Müller, 2443-Vila Ipiranga, 79074-460. E-mail: thaina.carvalho09z@gmail.com

Ruy Alberto Caetano Corrêa Filho

Faculdade de Medicina Veterinária e Zootecnia da Universidade Federal de Mato Grosso do Sul (UFMS). Avenida Senador Filinto Müller, 2443-Vila Ipiranga, 79074-460. E-mail: ruy.filho@ufms.com

Received: Aug. 30, 2020

Accepted: Sep. 20, 2020

Published: Oct. 15, 2020

doi:10.5296/jas.v8i4.17598

URL: https://doi.org/10.5296/jas.v8i4.17598

\begin{abstract}
The objective of this study was to evaluate the performance of Nile tilapia and the lettuce, watercress, and arugula vegetables in a gravel-bed aquaponic system using the aerated fish tank-to-vegetable growing bed volume ratios of 1:1 and 1:2. Each experimental unit consisted of an aquaponic module composed of two containers: one to allocate the vegetables (500-L tank with gravel, measuring $2 \mathrm{~m}^{2}$ ) and another to stock fish at the ratios of 1:1 (500-L vegetable:500-L fish tank) and 1:2 (500-L vegetable tank:1000-Lfish tank). The experiment was laid out in a randomized-block design with two treatments (500-L fish tank $\times 1000$-L fish tank) and three blocks (periods). The performance of the Nile tilapia and of the vegetables did not differ significantly in response to the increasing fish tank volume, with the fish and the vegetables exhibiting good performance results in both volume ratios. In conclusion, in aquaponics, the fish tank-to-vegetable tank volume ratios of 1:1 and 1:2 are equally effective for the production of Nile tilapia and the lettuce, watercress and arugula vegetables.
\end{abstract}

Keywords: lettuce, watercress, Oreochromis niloticus, aquiculture systems, arugula

\title{
1. Introduction
}

Technological innovations in aquaculture are important to maximize production and reduce environmental impacts. Aquaponics emerges to attend to these needs, as it associates aquiculture with hydroponics, in which the water from fish production, which is rich in nutrients, is used to irrigate the vegetables (Rakocy, 2012; Trang et al., 2017). In aquaponics, 
fish receive feed and excrete waste that is used by microorganisms to transform ammonia into nitrite and, later, into nitrate, a form that is absorbable by plants (Rakocy et al., 2006).

Aquaponics is practiced in various models and volumes, which include NFT (Nutrient Film Technique) or pipes, which consists of an aquaponic system formed by structures of PVC tubes placed horizontally, with plants allocated inside the holes in the upper part of the tubes (Somerville et al., 2014); DWC (Deep Water Culture) or floating/raft aquaponic system, which combines the simplicity of handling the harvest and the planting of seedlings, as they are allocated in floating plates with spaced holes (Tokunaga et al., 2015); and MFB (Media-Filled Bed), which is formed by simple structures composed of a tank or water box for fish and a bench with a container with gravel or similar material to accommodate the vegetables, which makes this system the most practical and functional (Maucieri et al., 2018).

Good performance results have been obtained for vegetables and fish, such as tilapia, in gravel aquaponic systems at different stocking densities (Babatunde et al., 2019), and better biomass gain and yield results were achieved as compared with the NFT and raft systems (Lennard and Leonard, 2006).

However, comparative information is lacking regarding the most efficient dimensions for the media-filled bed aquaponic system for the production of Nile tilapia and the lettuce, watercress and arugula vegetables. Thus, appropriate volumes must be defined for Nile tilapia farming to maximize vegetable production performance. The aim of this study was to evaluate the performance of Nile tilapia and the lettuce, watercress and arugula vegetables in a gravel aquaponic system at aerated fish tank-to-vegetable growing bed volume ratios of 1:1 (500-L vegetable tank:500-L fish tank) and 1:2 (500-L vegetable tank:1000-L fish tank).

\section{Material and Methods}

\subsection{Experimental System}

The experiment was carried out at the Fish Farming sector at the Federal University of Mato Grosso do Sul, located in Campo Grande, MS, Brazil. All experimental procedures used in the research were approved by the Animal Use Ethics Committee (CEUA) - Federal University of Mato Grosso do Sul (approval no. 889/2017).

The experiment was laid out in a randomized-block design with two treatments (500-L fish tank $\times 1000$-L fish tank) and three blocks, which were used to control the periods variable. The modules performed three water discharges per hour. The experimental unit was the aquaponic module composed of two tanks: one to allocate the vegetables and the gravel (500-L volume tank and with 2- $\mathrm{m}^{2}$ surface, gravel with a size of $1.5-2 \mathrm{~cm}$, placed at a height of $25-27 \mathrm{~cm})$ and another with aeration to stock fish at the ratios of 1:1 (500-L vegetable tank:500-L fish tank) and 1:2 (500-L vegetable tank:1000-L fish tank).

In aquaponics, a Bell siphon was used to create a flood and drainage system in the vegetable growing bed. The effluent from the fish tank was pumped to the vegetable tank using a 44-W submerged pump (JAD FP-58). The water from the vegetable growing bed returned to the fish tank by gravity through a 32-mm PVC drain tube connected to the Bell siphon (vertical 
32-mm PVC tube, 50-mm bell siphon and a 100-mm media-guard). The vegetable tank drained in five minutes and took 14 min to be completely filled, which totaled three renewals per hour. Continuous aeration was provided for each Nile tilapia tank by an aeration system with an electromagnet compressor $(160 \mathrm{~L} / \mathrm{h})$.

The species used in the test was Nile tilapia (Oreochromis niloticus), which was farmed at a density of $4 \mathrm{~kg} / \mathrm{m}^{3}$ that corresponded to $12 \mathrm{fish} / \mathrm{m}^{3}$. The modules had independent water recirculation. The 500-L gravel tank was used to allocate the vegetables, with 40 seedlings of watercress (Rorippa nasturtium-aquaticum) $\left(0.120 \mathrm{~kg} / \mathrm{m}^{2}\right), 20$ seedlings of crisp lettuce (Lactuva sativa) $\left(0.120 \mathrm{~kg} \mathrm{~m}^{2}\right)$ and 40 seedlings of arugula (Eruca sativa) $\left(0.160 \mathrm{~kg} / \mathrm{m}^{2}\right.$ ) per unit, which corresponded to 50.0 seedlings $/ \mathrm{m}^{2}$. To stabilize the aquaponic systems, fertilizer urea was used and water previously matured with bacteria and algae was inoculated (Pereira and Mercante, 2005).

\subsection{Performance Variables}

Biometric measurements were performed at the start and end (40 days) of the experimental period. Before each of these measuring events, the fish were fasted for $24 \mathrm{~h}$ and then anesthetized with eugenol at the concentration of $50 \mathrm{mg} / \mathrm{L}$ (Vidal et al., 2008). The following performance variables were evaluated in the Nile tilapia: final weight $(\mathrm{g})$; apparent feed conversion \{Feed intake in the period, in $\mathrm{kg} /[$ (Initial number of fish + Final number of fish)/2 $]^{*}$ (Final weight, in $\mathrm{kg}$ - Initial weight, in $\mathrm{kg}$ ) $\}$; survival $\{[(12-($ Final number of fishInitial number of fish)/12]*100\}; daily weight gain [(Final weight, g - Initial weight, in g)/30 days]; final biomass [(Final weight, in $\mathrm{g} *$ Final number of fish* $1000 \mathrm{~L}$ ) in $\mathrm{kg}$ ] and biomass gain (Final biomass - Initial biomass, in $\mathrm{kg}$ ). The vegetables were weighed individually and the following weights were recorded: lettuce leaves $(\mathrm{g})$, lettuce roots $(\mathrm{g})$, whole lettuce $(\mathrm{g})$, lettuce biomass $(\mathrm{kg})$, watercress biomass $(\mathrm{kg})$, arugula leaves $(\mathrm{g})$, arugula roots $(\mathrm{g})$, whole arugula $(\mathrm{g})$, arugula biomass $(\mathrm{kg})$ and total vegetable biomass $(\mathrm{kg})$.

\subsection{Feeding Management and Water Quality}

The fish were fed a commercial extruded feed with a 6- to 8 - $\mathrm{mm}$ pellet (32\% crude protein, $6.5 \%$ ether extract, $4 \%$ crude fiber, $14 \%$ mineral matter and $12 \%$ moisture). The feed was supplied to apparent satiety, twice daily, at $08 \mathrm{~h} 00$ and $17 \mathrm{~h} 00$.

Water temperature $\left({ }^{\circ} \mathrm{C}\right)$, dissolved oxygen $(\mathrm{mg} / \mathrm{L})$ and $\mathrm{pH}$ were measured daily with probes (YSI Professional). Ammonia $\left(\mathrm{NH}_{3}\right)$, total ammonia nitrogen (TAN) and nitrite $\left(\mathrm{NO}_{2}{ }^{-}\right)$were determined twice a week using colorimetric kits (Alfakit). Solids from the remaining feed and feces were siphoned and water lost through evaporation was replaced weekly.

\subsection{Analysis}

Analysis of variance was performed with effects of treatments and blocks as the sources of variation and fish initial weight as the co-variable. The data were analyzed using the GLM procedure of SAS 9.0 statistical software. 


\section{MInstitute"}

\section{Results}

The water quality variables were maintained at adequate levels and did not differ $(\mathrm{P}>0.05)$ in the different tank volumes of Nile tilapia production in an aquaponic system (Table 1).

Table 1. Physico-chemical characteristics of water from Nile tilapia production in a gravel aquaponic system at aerated fish tank-to-vegetable growing bed volume ratios of 1:1 (500-L vegetable tank:500-L fish tank) and 1:2 (500-L vegetable tank:1000-L fish tank)

\begin{tabular}{lcccc}
\hline \multirow{2}{*}{ Variable } & \multicolumn{3}{c}{ Ratio between tanks } & \\
\cline { 2 - 3 } & $1: 1$ & $1: 2$ & $\mathrm{CV}(\%)^{(1)}$ & P value \\
\hline Temperature $\left({ }^{\circ} \mathrm{C}\right)$ & 24.96 & 25.12 & 0.33 & 0.15 \\
$\mathrm{pH}$ & 7.50 & 7.52 & 0.19 & 0.42 \\
Dissolved oxygen $\left(\mathrm{mg} \mathrm{L}^{-1}\right)$ & 4.37 & 4.07 & 10.82 & 0.51 \\
Total ammonia nitrogen $\left(\mathrm{mg} \mathrm{L}^{-1}\right)$ & 0.42 & 0.45 & 19.58 & 0.71 \\
Ammonia $\left(\mathrm{mg} \mathrm{L}^{-1}\right)$ & 0.02 & 0.02 & 18.84 & 0.42 \\
Nitrite $\left(\mathrm{mg} \mathrm{L}^{-1}\right)$ & 0.05 & 0.09 & 21.54 & 0.06 \\
\hline
\end{tabular}

(1) Coefficient of variation.

There was no significant difference by Student's T test $(\mathrm{P}>0.05)$.

The final weight, weight gain, daily weight gain, final biomass, biomass gain and apparent feed conversion of Nile tilapia did not differ $(\mathrm{P}>0.05)$ when they were grown in the tank volumes of $500 \mathrm{~L}$ and $1000 \mathrm{~L}$ (Table 2). The leaf, root and whole-vegetable weights of lettuce and arugula did not differ $(\mathrm{P}>0.05)$ when the fish were grown in 500-L and 1000-L tanks. Likewise, the biomasses of lettuce, watercress and arugula and the total biomass of the vegetables did not differ $(\mathrm{P}>0.05)$ when the fish were grown in 500-L and 1000-L tanks (Table 3).

Table 2. Performance variables of Nile tilapia in a gravel aquaponic system at aerated fish tank-to-vegetable growing bed volume ratios of 1:1 (500-L vegetable tank:500-L fish tank) and 1:2 (500-L vegetable tank:1000-L fish tank)

\begin{tabular}{lcccc}
\hline \multirow{2}{*}{ Variable } & \multicolumn{3}{c}{ Ratio between tanks } & \\
\cline { 2 - 5 } & $1: 1$ & $1: 2$ & $\mathrm{CV}(\%)^{(1)}$ & P value \\
\hline Final weight $\left(\mathrm{kg} / \mathrm{m}^{3}\right)$ & 0.436 & 0.443 & 2.05 & 0.68 \\
Apparent feed conversion & 1.68 & 1.50 & 16.67 & 0.70 \\
Survival & 95.64 & 96.01 & 0.66 & 0.58 \\
Daily weight gain $(\mathrm{g} /$ day) & 2.55 & 2.77 & 11.31 & 0.67 \\
Final biomass $\left(\mathrm{kg} / \mathrm{m}^{3}\right)$ & 4.71 & 4.60 & 1.43 & 0.43 \\
Biomass gain $\left(\mathrm{kg} / \mathrm{m}^{3}\right)$ & 0.88 & 0.71 & 17.27 & 0.52 \\
\hline
\end{tabular}

(1) Coefficient of variation.

There was no significant difference by Student's T test $(\mathrm{P}>0.05)$. 
Table 3. Production performance variables of vegetables grown in a gravel aquaponic system at aerated fish tank-to-vegetable growing bed volume ratios of 1:1 (500-L vegetable tank:500-L fish tank) and 1:2 (500-L vegetable tank:1000-L fish tank)

\begin{tabular}{lcccc}
\hline \multirow{2}{*}{ Variable } & \multicolumn{3}{c}{ Proportion between tanks } & \\
\cline { 2 - 5 } & $1: 1$ & $1: 2$ & $\mathrm{CV}(\%)^{(1)}$ & P value \\
\hline Lettuce leaves $(\mathrm{g})$ & 64 & 90 & 29.55 & 0.54 \\
Lettuce roots $(\mathrm{g})$ & 16 & 31 & 17.50 & 0.24 \\
Lettuce biomass $\left(\mathrm{kg} / \mathrm{m}^{2}\right)$ & 1.62 & 1.42 & 18.87 & 0.36 \\
Watercress biomass $\left(\mathrm{kg} / \mathrm{m}^{2}\right)$ & 1.30 & 1.80 & 15.00 & 0.35 \\
Arugula leaves $(\mathrm{g})$ & 11 & 20 & 27.42 & 0.37 \\
Arugula roots $(\mathrm{g})$ & 4 & 6 & 26.12 & 0.45 \\
Arugula biomass $\left(\mathrm{kg} / \mathrm{m}^{2}\right)$ & 0.51 & 0.64 & 86.87 & 0.88 \\
Total biomass $\left(\mathrm{kg} / \mathrm{m}^{2}\right)$ & 3.44 & 4.88 & 26.96 & 0.51 \\
\hline
\end{tabular}

(1) Coefficient of variation.

There was no significant difference by Student's T test $(\mathrm{P}>0.05)$

\section{Discussion}

The increase in the volume of fish production tanks from $500 \mathrm{~L}$ to 1000 (maintaining the fish density and the volume of the vegetable growing bed at $500 \mathrm{~L}$ ) did not change water quality. The water characteristics were within the range considered adequate for tropical fish (Boyd, 1998).

Increasing the volume of the fish production tanks from 500 to $1000 \mathrm{~L}$ while maintaining the fish density $\left(12 \mathrm{fish} / \mathrm{m}^{3}-4 \mathrm{~kg} / \mathrm{m}^{3}\right)$ and the volume of the vegetable growing bed $(500 \mathrm{~L})$ did not improve the performance of the fish, which was possibly due to the maintenance of the water quality and of the fish stocking density. The effect of Nile tilapia density in gravel aquaponic system on performance was demonstrated by Babatunde et al. (2019), who found a decrease in final weight (57.5 to $42.0 \mathrm{~g})$, weight gain $(43.2$ to $34.0 \mathrm{~g})$ and daily weight gain $\left(1.0\right.$ to $0.79 \mathrm{~g} /$ day) as density was increased from $100 \mathrm{fish} / \mathrm{m}^{3}\left(5.7 \mathrm{~kg} / \mathrm{m}^{3}\right)$ to $250 \mathrm{fish} / \mathrm{m}^{3}(10.0$ $\mathrm{kg} / \mathrm{m}^{3}$ ). The performance results obtained in the present study are adequate, considering values obtained with Nile tilapia in net-tanks (Moraes et al., 2009) (biomass gain: $0.476 \mathrm{~kg}$; feed conversion: 1.59), in fish ponds (Assano et al., 2011) (daily weight gain: $2.37 \mathrm{~g} / \mathrm{day}$; feed conversion: 1.3) and in aquaponics with biofloc technology (BFT) (Lima et al., 2015) (daily weight gain: 2.16 to $2.36 \mathrm{~g}$ /day; feed conversion: 1.38 to 1.62 ).

In addition to the fish density in the fish production tank, the type of vegetable used in aquaponics interferes with the performance of Nile tilapia when produced in an NFT aquaponic system (Effendi et al., 2017). This is due to the efficiency of the plant to absorb the nitrogen compounds produced by fish. Thus, it can be inferred that, in the present study, the tank management and the vegetable types and densities were adequate to provide water quality for the fish to develop properly.

It is noteworthy that the increase in the volume of the tanks where the fish were produced did not improve the performance of lettuce, watercress or arugula, whether in the leaves, roots, whole vegetable or final biomass. This result indicates that the availability of nutrients in the fish tank volumes of 500 and $1000 \mathrm{~L}$ was enough for the vegetables growth. In this respect, 
perhaps, a larger volume ( $>500 \mathrm{~L})$ in the vegetable growing beds associated with a larger volume in the fish production tanks $(1000 \mathrm{~L})$ could increase the final biomass of the vegetables without impairing individual performance, as it would increase the amount of substrate to make nutrients available to the plants.

The performance obtained for whole lettuce in the present study can be deemed satisfactory, considering that Sace and Fitzsimmons (2013) used NFT aquaponics and found more than the double the weight in the period of 108 days of experiment with lettuce. In their experiment, lettuce showed a lower whole-vegetable weight $(75.5 \mathrm{~g})$ than that found in the present study (80 and $121 \mathrm{~g}$ ). The authors also used Nile tilapia, but in 250-L production tanks. In addition to the water volume in the vegetable growing bed (which did not interfere with the performance of the vegetables, in the present experiment), the weight and biomass of vegetables depend on other factors, such as the type of substrate used in the aquaponic tanks (Rakocy et al., 2006), climatic conditions (Love et al., 2015), type of aquatic organism species produced in aquaponics (Sace and Fitzsimmons, 2013), quantity and quality of feed (Rakocy, 2012), aquaponics type (Carneiro et al., 2015) and plant variety (Pinho et al., 2017).

It is important to highlight the great efficiency of the aquaponics system in the production of vegetables as compared with other fish production systems. Pinho et al. (2017) found a larger biomass of the lettuce varieties red $\left(0.56 \mathrm{~kg} / \mathrm{m}^{2}\right)$, butter $\left(1.94 \mathrm{~kg} / \mathrm{m}^{2}\right)$ and crispy $\left(1.36 \mathrm{~kg} / \mathrm{m}^{2}\right)$ in a raft aquaponics system (with BFT) in relation to the clear water system (red $0.28 \mathrm{~kg} / \mathrm{m}^{2}$; butter: $1.53 \mathrm{~kg} / \mathrm{m}^{2}$; and crispy: $1.04 \mathrm{~kg} / \mathrm{m}^{2}$ ) in 500 -L fish production tanks during 21 days. Although the authors did not work with the crisp lettuce variety (the variety used in the present study), there was a great difference in the performance of the different lettuce varieties, with the red variety showing inferior results than the crisp lettuce in the present study.

The larger biomass of lettuce and watercress indicate that these vegetables are more suitable for production in aquaponics in relation to arugula in the tank volumes, fish species and fish density used. Similar results were observed by Lennard and Ward (2019), who reported a whole-arugula weight of $10.7 \mathrm{~g}$ with a growing period of 42 days in an NFT aquaponic system, which is close to the $14 \mathrm{~g}$ obtained in the current study. These authors showed better performance of the lettuce varieties (seven varieties) as compared with arugula, suggesting that the latter is less adapted to aquaponics than other vegetables, with values almost three times lower than when produced in hydroponics in the same period $(31 \mathrm{~g})$, which the present findings corroborate. Although there is a difference between the varieties, lettuce showed results close to those obtained in aquaponics by Pinho et al. (2017). Likewise, watercress also exhibited values close to those obtained in other studies with raft aquaponics, e.g. Nhan et al. (2019) at the density of 180 plants $/ \mathrm{m}^{2}$ (final biomass of $0.460 \mathrm{~kg}$ of watercress $/ \mathrm{m}^{2}$ ).

It should be noted that although there was no significant difference in the performance of the vegetables, higher mean values (non-significant) were found for the three vegetables and total vegetable biomass when the larger tank volume was used for fish production $(1000 \mathrm{~L})$ as compared with the lower volume $(500 \mathrm{~L})$. This indicates that the increase in the volume of production tanks for these vegetables might also represent an increase in their own 
performance. Other studies evaluating different ratios and volumes of vegetable production tanks are warranted to corroborate this hypothesis.

\section{Conclusion}

The aerated fish tank-to-vegetable growing bed volume ratios of 1:1 (500 L:500 L) and 1:2 (500 L:1000 L) are equally effective for the performance of Nile tilapia and of the lettuce, watercress and arugula vegetables.

\section{Acknowledgments}

This study was financed in part by Coordenação de Aperfeiçoamento de Pessoal de Nível Superior - Brazil (CAPES) - Finance Code 001; Fundação Universidade Federal de Mato Grosso do Sul - UFMS/MEC - Brazil; and Fundação de Apoio ao Desenvolvimento do Ensino, Ciência e Tecnologia do Estado de Mato Grosso do Sul (FUNDECT) as a Doctoral fellowship (FUNDECT Call no. 03/2017).

\section{References}

Assano, M., Ramirez, A. P. M., Stech, M. R., Honorato, C. A., Malheiros, E. B., \& Carneiro, D. J. (2011). Desempenho da tilápia-do-nilo cultivadas em viveiros com diferentes fontes e níveis de proteína. Ciências Agrárias, Biológicas e Saúde, 15, 81-90.

Babatunde, T. A., Ibrahim, K., Abdulkarim, B., Wagini, N. H., \& Usman, S. A. (2019). Co-production and biomass yield of amaranthus (Amaranthus hybridus) and tilapia (Oreochromis niloticus) in gravel-based substrate filter aquaponic. International Journal of Recycling of Organic Waste in Agriculture, 8, 255-261. https://doi.org/10.1007/s40093-019-00297-5

Boyd, C. E. (1998). International Center for Aquaculture and Aquatic Environments, Alabama Agricultural Experiment Station, Auburn University.

Carneiro, P. C. F., Maria, N. A., Nunes, M. U. C., \& Fujimoto, R. Y. (2015). Aquaponia: produção sustentável de peixes e vegetais. In: Tavares-Dias, M. and Mariano, W.S. (Org.). Aquicultura no Brasil: novas perspectivas, 683-706.

Effendi, H., Wahyuningsih, S., \& Wardiatno, Y. (2017). The use of nile tilapia (Oreochromis niloticus) cultivation wastewater for the production of romaine lettuce (Lactuca sativa L. var. longifolia) in water recirculation system. Applied Water Science, 7, 3055-3063. https://doi.org/10.1007/s13201-016-0418-z

Lennard, W., \& Leonard, B. V. (2006). A comparison of three different hydroponic sub-systems (gravel bed, floating and nutrient film technique) in an Aquaponic test system. Aquaculture International, 14, 539-550. https://doi.org/10.1007/s10499-006-9053-2

Lennard, W., \& Ward, J. (2019). A Comparison of Plant Growth Rates between an NFT Hydroponic System and an NFT Aquaponic System. Horticulturae, 27, 1-16. https://doi.org/10.3390/horticulturae5020027

Lima, E. C. R., Souza, R. L., Wambach, X. F., Silva, U. L., \& Correia, E. S. (2015). Cultivo 
da tilápia do Nilo Oreochromis niloticus em sistema de bioflocos com diferentes densidades de estocagem. Revista brasileira de saúde e produção animal, 16, 948-957.

https://doi.org/10.1590/S1519-99402015000400018

Love, D. C., Fry, J. P., \& Li, X. (2015). Commercial aquaponics production and profitability: findings from an international survey. Aquaculture, 435, 67-74.

https://doi.org/10.1016/j.aquaculture.2014.09.023

Maucieri, C., Nicoletto, C., Junge, R., Schmautz, Z., Sambo, P., \& Borin, M. (2018). Hydroponic systems and water management in aquaponics: A review. Italian Journal of Agronomy, 13, 1012-1023. https://doi.org/10.4081/ija.2017.1012

Moraes, A. M., Seiffert, W. Q., Tavares, F., \& Fracalossi, D. M. (2009). Desempenho zootécnico de tilápia do Nilo, Oreochromis niloticus, em tanques-rede, com diferentes rações comerciais. Revista Ciência Agronomica, 40, 388-395.

Nhan, H. T., Taia, N. T., Liema, P. T., Uta, U. N., \& Ako, H. (2019). Effects of different stocking densities on growth performance of Asian swamp eel Monopterus albus, water quality and plant growth of watercress Nasturtium officinale in an aquaponic recirculating system. Aquaculture, 503, 96-104. https://doi.org/10.1016/j.aquaculture.2018.12.067

Pereira, L. P. F., \& Mercante, C. T. J. (2005). A amônia nos sistemas de criação de peixes e seus efeitos sobre a qualidade da água. Uma revisão. Boletim Instituto de Pesca, 31, 81-88.

Pinho, S. M., Molinari, D., Mello, G. L., Fitzsimmons, K. M., \& Emerenciano, M. G. C. (2017). Effluent from a biofloc technology (BFT) tilapia culture on the aquaponics production of different lettuce varieties. Ecological Engineering, 103, 146-153.

https://doi.org/10.1016/j.ecoleng.2017.03.009

Rakocy, J. E. (2012). Aquaponics - Integrating fish and plant culture; Wiley-Blackwell: Hoboken, NJ, USA. 344-386. https://doi.org/10.1002/9781118250105.ch14

Rakocy, J. E., Losordo, T. M., \& Masser. M. P. (2006). Recirculating aquaculture tank production systems: Aquaponics - Integrating fish and plant culture. Southern Reg. Aquaculture Center Publications, 454.

Sace, C. F., \& Fitzsimmons, K. M. (2013). Recirculating aquaponic systems using nile tilapia (Oreochromis niloticus) and freshwater prawn (Macrobrachium rosenbergii) polyculture and the productivity of selected leafy vegetables. Research Journal Business Management, 1, 11-29.

Somerville, C., Cohen, M., Pantanella, E., Stankus, A., \& Lovatelli, A. (2014). Small-scale aquaponic food production. Integrated fish and plant farming. FAO Fisheries and Aquaculture Technical Paper, 589, 262p.

Tokunaga, K., Tamaru, C., Ako, H., \& Leung, P. (2015). Economics of Small - scale Commercial Aquaponics in Hawaii. World Aquaculture Society, 46, 20-32.

https://doi.org/10.1111/jwas.12173 
Trang, N. T. D., Konnerup, D., \& Brix, H. (2017). Effects of recirculation rates on water quality and Oreochromis niloticus growth in aquaponic systems. Aquacultural Engineering, 78, 95-104. https://doi.org/10.1016/j.aquaeng.2017.05.002

Vidal, L. V. O., Albinati, R. C. B., Albinati, A. C. L., Lira, A. D., Almeida, T. R., \& Santos, G. B. (2008). Eugenol como anestésico para a tilápia-do-nilo. Pesquisa Agropecuária brasileira, 43, 1069-1074. https://doi.org/10.1590/S0100-204X2008000800017

\section{Copyright Disclaimer}

Copyright for this article is retained by the author(s), with first publication rights granted to the journal.

This is an open-access article distributed under the terms and conditions of the Creative Commons Attribution license (http://creativecommons.org/licenses/by/4.0/). 